\title{
Symbiotic, Hypocholesterolemic and Antioxidant Effects of Potential Probiotic Lactobacilli Strains Isolated from Tunisian Camel Milk
}

\author{
Imen Mahmoudi, Olfa Ben Moussa, Mnasser Hassouna \\ Unité de Recherche Bio-Conservation et Valorisation des Produits Agro-Alimentaires, Tunis, Tunisia \\ Email: imenmahmoudi15@yahoo.fr
}

How to cite this paper: Mahmoudi, I., Ben Moussa, O. and Hassouna, M. (2017) Symbiotic, Hypocholesterolemic and Antioxidant Effects of Potential Probiotic Lactobacilli Strains Isolated from Tunisian Camel Milk. Advances in Microbiology, 7, 328-342. https://doi.org/10.4236/aim.2017.74027

Received: March 8, 2017

Accepted: April 27, 2017

Published: April 30, 2017

Copyright (c) 2017 by authors and Scientific Research Publishing Inc. This work is licensed under the Creative Commons Attribution International License (CC BY 4.0).

http://creativecommons.org/licenses/by/4.0/

\section{(c) (i) Open Access}

\begin{abstract}
In the present study, 20 selected Lactobacillus strains already characterized in a previous research for their capability to grow in conditions simulating the intestinal environment, their resistance to antibiotics, their antibacterial activity and their adhesion capability to intestinal human Caco-2 TC7 and HT-29 MTX cell lines, were further investigated to explore more their probiotic properties. Growth behaviour in the presence of prebiotic (fructooligosaccharides (FOS) and lactulose) at a concentration of $2 \%$, cholesterol removal by measuring the residual cholesterol in medium supplemented with cholesterol, ability to deconjugate bile salts using BSH enzyme and antioxidant activity of culture supernatant of Lactobacillus strains by $\mathrm{ABTS}^{+}$and DPPH methods were analyzed. All probiotic strains demonstrated important prebiotic assimilation $(\mathrm{P}>0.05)$ even with $\mathrm{OD}_{600}>3$ after $30 \mathrm{~h}$ of contact, cholesterol removal ability with maximum percentage of $57 \%$ after $24 \mathrm{~h}$ of contact and they were found to liberate significantly $(\mathrm{P}<0.05)$ more cholic acid with maximum of $0.40 \mathrm{mM}$ of sodium glycocholate, $0.33 \mathrm{mM}$ of sodium taurocholate and 0.41 $\mathrm{mM}$ of their mixte and scavenge both radicals with $52 \%$ and $2.19 \%$ of ABTS $^{+}$ and DPPH respectively. This study confirmed the suitability of these probiotic strains for application in functional food formulations especially where cholesterol reduction and antioxidant activity in food are needed to assess possible in vivo human health benefits.
\end{abstract}

\section{Keywords}

Probiotic, Prebiotic, Cholesterol Removal, Bile Salt Deconjugation, Antioxidant Activity, Functional Food 


\section{Introduction}

Identifying microorganisms all over the world and characterizing their metabolites are crucial steps in the study of human nutrition [1]. The term "probiotics" was defined as the active factors, when consumed in sufficient quantities, stimulating the growth of other microorganisms and apporting beneficial effects on host health [2].

Milk and dairy products have not been only characterized by their high nutritional value, but also by their ability to exert positive effects on the consumer's health as functional foods [3]. In this context, non digestible ingredients, such as prebiotics, have received important attention, because of their ability to stimulate selectively the growth and activity of probiotic bacteria in the colon [4]. However, the ability of probiotic microorganisms to use the prebiotics is strain and substrate dependent [5].

To have effects, prebiotics must escape digestion in the gastrointestinal tract and be used by the colonic microflora, mostly lactobacilli and bifidobacteria [6]; thus, after that, they are referred to bifidogenic factors [7]. Infrequently, prebiotics are reported to alleviate the virulence of pathogens like Listeria monocytogenes [8]. This family of compounds includes several oligosaccharides, inulin, lactulose, lactosucrose,... [9].

Bioactive components of functional foods and natural health products are responsible for their efficacy in disease prevention, therefore, they have been recommended as a favorable dietary technique to reduce cholesterol, [10]. Also, it is reported that these products reduce the risk of coronary heart disease and therefore, the characterization of the active ingredients and the type of the probiotics is very requisite [11].

Mann and Spoerry [12] were the first to demonstrate that the consumption of milk fermented with Lactobacillus acidophilus reduced serum cholesterol in hypercholesterolaemic African subjects. Since then, the hypocholesterolamic effect of fermented dairy products has been investigated in human nutrition [13]. These studies suggest that Lactobacillus strains could eliminate total cholesterol and reduce density lipoprotein (LDL) cholesterol, which is a promoter facteur on serum cholesterol levels [14].

Many researchs have revealed that ingestion of lactic acid bacteria could diminish cholesterol levels in animals [15] and humans [16]. Although the exact mechanism of cholesterol reduction by probiotic bacteria was unclear. Several mechanisms have been suggested [17], such as removal of cholesterol [18], transformation of cholesterol [17] and enzymatic deconjugation of bile salts by producing bile salt hydrolase (BSH) [19]. Besides, the hydrolyse of bile salts has often been included amongst the criteria for probiotic selection. Probiotics are able to hydrolyse glycin- or taurin-conjugated bile salts into amino acid residues and free bile salts [20]. Conjugated bile salts are usually re-circulated through enterohepatic circulation, whilst deconjugated bile salts are less soluble and are excreted in the faeces [21]. The excreted bile salts are replaced by new bile salts formed from cholesterol in the blood stream. Thus, the more bile salt excreted, 
the more cholesterol is removed from the blood stream [22]. Many studies have shown that some strains of Lactobacillus acidophilus secrete BSH and deconjugate bile salts [22]; however, others have found no relationship between the amount of in vitro cholesterol removal and the degree of bile salt deconjugation [23]. These conflicting results lead to the suggestion of another mechanism, which may be associated with cholesterol assimilation from the media into the cellular membrane of probiotic bacteria during growth [17].

Also, antioxidant activity is one of the essential roles of probiotics which consists in the protection of cells and tissues from oxidation damage [24]. Thus, the aim of this study was to evaluate the growth behaviour in the presence of prebiotic carbohydrates, cholesterol removal ability via cholesterol assimilation, bile salt deconjugation and antioxidant properties of twenty Lactobacillus strains.

\section{Materials and Methods}

\subsection{Bacteria and Growth Conditions}

Twenty probiotic strains isolated from camel milk were identified and characterized in previous research of Mahmoudi et al. [25] with modified nominations. These included fourteen Lactobacillus fermentum strains CAT2 (B2), CAT19 (B19), СAT23 (B23), СAT28 (B28), СAT29 (B79), CAT40 (B90), САT43 (B93), CAT47 (B97), CAT53 (B103), CABA4 (B104), CABA7 (B107), CABA16 (B116), CABA42 (B142) and CABA56 (B156) and six Lactobacillus plantarum CAKA28 (B128), CAKA34 (B134), CAN23 (B143), CAN29 (B149), CAN36 (B166) and CAN38 (B174). The stock cultures were stored in $20 \%$ of glycerol at $-80^{\circ} \mathrm{C}$. The cultures were activated by triplicate subculturing in de Mann Rogosa Sharpe (MRS) broth (Biokar Diagnostics) using $1 \%$ of inoculum and incubation at $37^{\circ} \mathrm{C}$ for $18-24 \mathrm{~h}$

\subsection{Growth in the Presence of Prebiotics}

Two prebiotics carbohydrates were used in this study; Fructoolisaccharides and lactulose (Sigma, France). Glucose was used as control growth carbohydrate. The analysis of growth capability in the presence of this carbohydrates of Lactobacillus strains was determined according to Pennachia et al. [26] with modificationss. $1 \mathrm{ml}$ of each overnight culture was transferred into a sterile tube and centrifuged (1000 rpm, $\left.10 \mathrm{~min}, 4^{\circ} \mathrm{C}\right)$. The pellet was then resuspended in $50 \mathrm{ml}$ of MRS broth and containing $2 \%(\mathrm{w} / \mathrm{w})$ of each prebiotic or control carbohydrate (glucose). Growth of probiotic strainsin presence of glucose and in presence of prebiotics were monitored after $0,8,24$ and $30 \mathrm{~h}$ of incubation at $37^{\circ} \mathrm{C}$ by measuring the absorbance at $600 \mathrm{~nm}$.

\subsection{Screening of Probiotic Lactobacillus Strains for Cholesterol Removal}

Cholesterol removal by probiotic Lactobacillus strains was determined according 
to the spectrophotometer method which previously described by Miremadi et al. [14]. $30 \mathrm{mg}$ of water-soluble cholesterol (poly-oxyethanyl-cholesterol sebacate) (Sigma, France) were dissolved in $10 \mathrm{ml}$ of milli-q water and filter-sterilized to obtain a stock solution of cholesterol. The MRS broth containing $0.3 \%$ of bile salt (oxgall; Sigma, France) and $100 \mu \mathrm{l} / \mathrm{ml}$ of cholesterol solution was inoculated with $1 \%$ of probiotic cultures and incubated at $37^{\circ} \mathrm{C}$ for $24 \mathrm{~h}$. After 6,12 , and 24 $\mathrm{h}$ interval incubation, each culture was centrifuged at $4000 \mathrm{rpm}$ for $20 \mathrm{~min}$ at $4^{\circ} \mathrm{C}$. After that, the mixture of $1 \mathrm{ml}$ of the supernatant, $1 \mathrm{ml}$ of $\mathrm{KOH}(33 \%$, w/v) and $2 \mathrm{~mL} \mathrm{96 \%} \mathrm{ethanol} \mathrm{was} \mathrm{vortexed} \mathrm{for} 1 \mathrm{~min}$ followed by incubation at $37^{\circ} \mathrm{C}$ for $15 \mathrm{~min}$, and cooled to room temperature. Then, $2 \mathrm{ml}$ of milli-q water and 3 $\mathrm{ml}$ of hexane were added to the mixture. For separation of the two layers, the upper hexane layer was collected and evaporated under nitrogen gas. Two millilitres of $o$-phthalaldehyde solution (Sigma, France) were added. To this, 0.5 $\mathrm{ml}$ of sulphuric acid (98\%; Sigma, France) was added and vortexed for $1 \mathrm{~min}$ followed by resting for $10 \mathrm{~min}$ at room temperature before measuring the absorbance at $550 \mathrm{~nm}$. The ability of probiotics to assimilate cholesterol was expressed as the percentage of cholesterol removed at each incubation interval as follows:

$$
\begin{aligned}
& \% \text { of cholesterol removed } \\
& =\frac{100-\text { residual cholesterol at each incubation interval }}{100} \times 100
\end{aligned}
$$

The cholesterol concentration was determined using a standard curve.

\subsection{Deconjugation of Bile Salts: Ammount of Free Cholic Acid}

The concentration of cholic acid was determined using spectrophotometer method as previously described by Miremadi et al. [14]. $10 \mathrm{ml}$ of MRS broth were supplemented with $6 \mathrm{mM}$ of sodium glycocholate, $6 \mathrm{mM}$ of sodium taurocholate, and a mixture of $2.8 \mathrm{mM}$ of sodium glycocholate and $1.2 \mathrm{mM}$ of sodium taurocholate [27]. Each mixture was inoculated with $1 \%$ activated probiotic followed by incubation for $24 \mathrm{~h}$ at $37^{\circ} \mathrm{C}$. After incubation, media was adjusted to $\mathrm{pH} 7.0$ with $\mathrm{NaOH}(1 \mathrm{M})$ and centrifugated at $4000 \mathrm{rpm}$ for $20 \mathrm{~min}$ at $4^{\circ} \mathrm{C}$. The supernatant was adjusted to $\mathrm{pH} 1.0$ with $\mathrm{HCl}(5 \mathrm{M}) .1 \mathrm{ml}$ from each supernatant was mixed with $2 \mathrm{ml}$ of ethyl acetate (Sigma, France), vortexed and the ethyl acetate layer was transferred into glass tubes and evaporated at $60^{\circ} \mathrm{C} .1 \mathrm{ml}$ of $\mathrm{NaOH}(0.01 \mathrm{M})$ was added to dissolve the residue, then, $1 \mathrm{ml}$ of furfuraldehyde $(1 \% ; \mathrm{v} / \mathrm{v})$ (Sigma, France) and $1 \mathrm{ml}$ of sulphuric acid (8 M). Glacial acetic acid was added upon cooling to the mixture after heating at $65^{\circ} \mathrm{C}$ for $10 \mathrm{~min}$. The amount of cholic acid was determined at $660 \mathrm{~nm}$ using exter-nal cholic acid standard curve.

\subsection{Antioxidant Capacity Using ABTS + Method}

The antioxidant activity was determined using ABTS $^{+}$(2,2 azino-bis (3-ethylbenzothiazoline-6-sulfonic acid)) radical cation method which previously des- 
cribed by Rossini et al. [28] and Pieniz et al. [24]. $\mathrm{ABTS}^{+}$was produced by reacting ABTS stock solution with potassium persulfate $(2.45 \mathrm{mM}$ ) (final concentration) and allowing the mixture to stand at room temperature for $16 \mathrm{~h}$ before use. This radical was dissolved in water $(7 \mathrm{mM})$. After that, the solution was used for a maximum of three days. Before anlyse, $\mathrm{ABTS}^{+}$solution was diluted with ethanol, to an absorbance of $0.700-0.020$ at $734 \mathrm{~nm}$.. Ascorbic acid was used as the standard in the range between $0-9 \mathrm{mg} / \mathrm{ml}$. After addition of 10 $\mathrm{ml}$ of each sample (or standards) in $1 \mathrm{ml}$ of $\mathrm{ABTS}^{+}$solution, the absorbance was determined for $5 \mathrm{~min}$. In another hand, ultrapure water was used as control. The percentage (\%) inhibition of absorbance at $734 \mathrm{~nm}$ was deterined using ascorbic acid standard curve.

\subsection{Scavenging Ability on 2,2-Diphenyl-1-Picrylhydrazyl (DPPH) Radicals}

This method was based on the capture of the DPPH radical (2,2-diphenyl-1picrylhydrazyl) by antioxidants, producing a decrease in absorbance at $515 \mathrm{~nm}$ [29]. The DPPH was dissolved at a concentration of $60 \mathrm{mM}$ in methyl alcohol. After homogenized, the solution was, transferred to a dark glass bottle and used only in the day of test. Then, $0.1 \mathrm{ml}$ of each sample (culture supernatant) was transferred to test tube containing $3.9 \mathrm{ml}$ of DPPH radical solution and homogenized by agitation. In another hand, a solution prepared from methyl alcohol (50\%), acetone andwater (70\%), mixed with $3.9 \mathrm{ml}$ of DPPH solution was used as control. Methyl alcohol was used as a blank. The results were determined using standard curve and expressed as EC50 $(\mu \mathrm{g} / \mathrm{ml})$, which is the minimum concentration to reduce $50 \%$ of the initial DPPH reaction from the time the extract reached stability.

\subsection{Statistical Analysis}

One-way ANOVA was employed to investigate these experiences followed by multiple mean comparisons Student's test. Results were presented as the mean \pm standard deviation of three repetitions. A P value $<0.05$ was considered statistically significant using SPSS 20.0.

\section{Results}

\subsection{Fermentation Capability of Prebiotic Carbohydrates}

The growth capability in medium containing $2 \%$ of prebiotic carbohydrates (FOS, and lactulose) and control (glucose) was tested for the 20 probiotic Lactobacillus strains by measuring absorbance at $600 \mathrm{~nm}$ at four times of incubation at $37^{\circ} \mathrm{C}$. After $30 \mathrm{~h}$ the data demonstrated no significative differences $(\mathrm{P}>0.05)$ in the bacterial growth rate (Table 1$)$.

In the presence of glucose, all the tested strains showed a very good growth behaviour during the $30 \mathrm{~h}$ of incubation at $37^{\circ} \mathrm{C}$, with $\mathrm{OD} 600$ values $>2.6$. The strains CAT19, CABA16 and CABA42 were to reach OD600 value $>3.0$ in this media. Also, They required after $8 \mathrm{~h}$ of incubation the stationary growth phase. 
Table 1. Growth of probiotic Lactobacillus strains in the presence of $2 \%$ of glucose. $2 \%$ of fructoolgosaccharides and $2 \%$ of lactulose.

\begin{tabular}{|c|c|c|c|c|c|c|c|c|c|c|c|c|}
\hline \multirow{3}{*}{$\begin{array}{c}\text { Probiotic } \\
\text { strains }\end{array}$} & \multicolumn{12}{|c|}{ Absorbance $(600 \mathrm{~nm})$} \\
\hline & \multicolumn{4}{|c|}{ Glucose } & \multicolumn{4}{|c|}{ Fructooligosaccharides } & \multicolumn{4}{|c|}{ Lactulose } \\
\hline & $\mathrm{Oh}$ & $8 \mathrm{~h}$ & $24 \mathrm{~h}$ & $30 \mathrm{~h}$ & $\mathrm{Oh}$ & $8 \mathrm{~h}$ & $24 \mathrm{~h}$ & $30 \mathrm{~h}$ & $0 \mathrm{~h}$ & $8 \mathrm{~h}$ & $24 \mathrm{~h}$ & $30 \mathrm{~h}$ \\
\hline \multicolumn{13}{|l|}{$\begin{array}{c}L . \\
\text { fermentum }\end{array}$} \\
\hline CAT2 & $0.09 \pm 0.01^{\mathrm{a}}$ & $2.46 \pm 0.014^{\mathrm{a}}$ & $2.74 \pm 0.1^{\mathrm{a}}$ & $2.74 \pm 0.1^{\mathrm{a}}$ & $0.03 \pm 0.1^{\mathrm{a}}$ & $1.9 \pm 0.1^{\mathrm{a}}$ & $1.65 \pm 0.1^{\mathrm{a}}$ & $1.69 \pm 0.1^{\mathrm{a}}$ & $0.08 \pm 0.1^{\mathrm{a}}$ & $2.4 \pm 0.07^{\mathrm{a}}$ & $2.7 \pm 0.1^{\mathrm{a}}$ & $2.71 \pm 0.01^{\mathrm{a}}$ \\
\hline CAT19 & $0.24 \pm 0.07^{\mathrm{a}}$ & $2.95 \pm 0.1^{\mathrm{a}}$ & $3.04 \pm 0.1^{\mathrm{a}} 3$ & $3.07 \pm 0.02^{\mathrm{a}}$ & $0.17 \pm 0.1^{\mathrm{a}}$ & $1.85 \pm 0.1^{\mathrm{a}}$ & $2.88 \pm 0.1^{\mathrm{a}}$ & $2.84 \pm 0.1^{\mathrm{a}}$ & $0.2 \pm 0.1^{\mathrm{a}}$ & $2.9 \pm 0.1^{\mathrm{a}}$ & $3 \pm 0.1^{\mathrm{a}}$ & $3 \pm 0.01^{\mathrm{a}}$ \\
\hline CAT23 & $0.17 \pm 0.1^{\mathrm{a}}$ & $2.86 \pm 0.1^{\mathrm{a}} 2$ & $2.91 \pm 0.07^{\mathrm{a}}$ & $2.92 \pm 0.1^{\mathrm{a}}$ & $0.1 \pm 0.1^{\mathrm{a}}$ & $1.56 \pm 0.1^{\mathrm{a}}$ & $1.6 \pm 0.1^{\mathrm{a}} \quad 1$ & $1.62 \pm 0.02^{\mathrm{a}} 0$ & $0.16 \pm 0.08^{\mathrm{a}}$ & $2.81 \pm 0.1^{\mathrm{a}}$ & $2.87 \pm 0.1^{\mathrm{a}}$ & $2.88 \pm 0.01^{\mathrm{a}}$ \\
\hline CAT28 & $0.2 \pm 0.1^{\mathrm{a}}$ & $2.88 \pm 0.13^{\mathrm{a}}$ & $2.94 \pm 0.1^{\mathrm{a}} 2$ & $2.97 \pm 0.13^{\mathrm{a}}$ & $0.15 \pm 0.1^{\mathrm{a}}$ & $1.75 \pm 0.1^{\mathrm{a}}$ & $1.81 \pm 0.1^{\mathrm{a}} 1$ & $1.87 \pm 0.02^{\mathrm{a}} 0$ & $0.18 \pm 0.01^{\mathrm{a}}$ & $2.84 \pm 0.1^{\mathrm{a}}$ & $2.9 \pm 0.016^{\mathrm{a}} 2$ & $2.93 \pm 0.01^{\mathrm{a}}$ \\
\hline СAT29 & $0.11 \pm 0.11^{\mathrm{a}}$ & $2.55 \pm 0.01^{\mathrm{a}}$ & $2.66 \pm 0.1^{\mathrm{a}}$ & $2.66 \pm 0.1^{\mathrm{a}}$ & $0.07 \pm 0.1^{\mathrm{a}} 1$ & $1.48 \pm 0.01^{\mathrm{a}}$ & $1.52 \pm 0.1^{\mathrm{a}} 1$ & $1.58 \pm 0.02^{\mathrm{a}}$ & $0.1 \pm 0.1^{\mathrm{a}}$ & $2.5 \pm 0.1^{\mathrm{a}}$ & $2.6 \pm 0.1^{\mathrm{a}}$ & $2.63 \pm 0.01^{\mathrm{a}}$ \\
\hline CAT40 & $0.14 \pm 0.12^{\mathrm{a}}$ & $2.87 \pm 0.17^{\mathrm{a}}$ & $2.92 \pm 0.1^{\mathrm{a}}$ & $2.97 \pm 0.09^{\mathrm{a}}$ & $0.1 \pm 0.02^{\mathrm{a}}$ & $1.77 \pm 0.01^{\mathrm{a}}$ & $1.82 \pm 0.1^{\mathrm{a}}$ & $1.91 \pm 0.1^{\mathrm{a}}$ & $0.09 \pm 0.1^{\mathrm{a}}$ & $2.8 \pm 0.1^{\mathrm{a}}$ & $2.87 \pm 0.1^{\mathrm{a}}$ & $2.89 \pm 0.01^{\mathrm{a}}$ \\
\hline CAT43 & $0.16 \pm 0.05^{\mathrm{a}}$ & $2.86 \pm 0.1^{\mathrm{a}}$ & $2.88 \pm 0.11^{\mathrm{a}} 2$ & $2.88 \pm 0.01^{\mathrm{a}}$ & $0.08 \pm 0.1^{\mathrm{a}} 1$ & $1.79 \pm 0.01^{\mathrm{a}}$ & $1.8 \pm 0.1^{\mathrm{a}}$ & $1.82 \pm 0.13^{\mathrm{a}} 0$ & $0.12 \pm 0.01^{\mathrm{a}}$ & $2.8 \pm 0.1^{\mathrm{a}}$ & $2.84 \pm 0.07^{\mathrm{a}} 2$ & $2.84 \pm 0.01^{\mathrm{a}}$ \\
\hline CAT47 & $0.12 \pm 0.01^{\mathrm{a}}$ & $2.86 \pm 0.21^{a}$ & $2.99 \pm 0.1^{\mathrm{a}}$ & $2.99 \pm 0.01^{\mathrm{a}}$ & $0.06 \pm 0.1^{\mathrm{a}}$ & $1.76 \pm 0.1^{\mathrm{a}}$ & $1.81 \pm 0.01^{\mathrm{a}}$ & $1.85 \pm 0.1^{\mathrm{a}} 0$ & $0.09 \pm 0.01^{\mathrm{a}}$ & $2.77 \pm 0.1^{\mathrm{a}}$ & $2.9 \pm 0.1^{\mathrm{a}}$ & $2.92 \pm 0.01^{\mathrm{a}}$ \\
\hline CAT53 & $0.09 \pm 0.01^{\mathrm{a}}$ & $2.46 \pm 0.02^{\mathrm{a}} 2$ & $2.84 \pm 0.15^{\mathrm{a}} 2$ & ${ }^{a} 2.87 \pm 0.01^{a}$ & $0.04 \pm 0.1^{\mathrm{a}}$ & $1.33 \pm 0.1^{\mathrm{a}}$ & $1.68 \pm 0.01^{\mathrm{a}}$ & $1.69 \pm 0.1^{\mathrm{a}} 0$ & $0.07 \pm 0.01^{\mathrm{a}} 2$ & $2.39 \pm 0.07^{\mathrm{a}}$ & $2.73 \pm 0.1^{\mathrm{a}}$ & $2.8 \pm 0.01^{\mathrm{a}}$ \\
\hline CABA4 & $0.18 \pm 0.01^{\mathrm{a}}$ & $2.86 \pm 0.1^{\mathrm{a}}$ & $2.9 \pm 0.01^{\mathrm{a}}$ & $2.95 \pm 0.1^{\mathrm{a}}$ & $0.08 \pm 0.13^{\mathrm{a}}$ & $1.72 \pm 0.1^{\mathrm{a}}$ & $1.81 \pm 0.01^{\mathrm{a}}$ & $1.87 \pm 0.1^{\mathrm{a}} 0$ & $0.15 \pm 0.01^{\mathrm{a}}$ & $2.84 \pm 0.1^{\mathrm{a}}$ & $2.85 \pm 0.1^{\mathrm{a}}$ & $2.85 \pm 0.01^{\mathrm{a}}$ \\
\hline CABA7 & $0.16 \pm 0.01^{\mathrm{a}}$ & $2.96 \pm 0.1^{\mathrm{a}}$ & $2.97 \pm 0.21^{\mathrm{a}}$ & $2.97 \pm 0.05^{\mathrm{a}}$ & $0.1 \pm 0.1^{\mathrm{a}}$ & $1.9 \pm 0.1^{\mathrm{a}}$ & $1.84 \pm 0.1^{\mathrm{a}}$ & $1.91 \pm 0.1^{\mathrm{a}}$ & $0.11 \pm 0.1^{\mathrm{a}}$ & $2.92 \pm 0.02^{\mathrm{a}}$ & $2.92 \pm 0.1^{\mathrm{a}}$ & $2.93 \pm 0.1^{\mathrm{a}}$ \\
\hline CABA16 & $0.28 \pm 0.01^{\mathrm{a}}$ & $3.06 \pm 0.02^{\mathrm{a}}$ & $3.22 \pm 0.1^{\mathrm{a}}$ & $3.27 \pm 0.1^{\mathrm{a}}$ & $0.25 \pm 0.02^{\mathrm{a}}$ & $1.86 \pm 0.1^{\mathrm{a}}$ & $2.91 \pm 0.1^{\mathrm{a}}$ & $3 \pm 0.1^{\mathrm{a}} \quad 0$ & $0.26 \pm 0.06^{\mathrm{a}}$ & $3 \pm 0.1^{\mathrm{a}}$ & $3 \pm 0.1^{\mathrm{a}}$ & $3.11 \pm 0.1^{\mathrm{a}}$ \\
\hline CABA42 & $0.18 \pm 0.01^{\mathrm{a}}$ & $2.89 \pm 0.1^{\mathrm{a}}$ & $3 \pm 0.1^{\mathrm{a}}$ & $3.01 \pm 0.07^{\mathrm{a}}$ & $0.1 \pm 0.01^{\mathrm{a}}$ & $1.7 \pm 0.1^{\mathrm{a}}$ & $1.9 \pm 0.1^{\mathrm{a}}$ & $2.31 \pm 0.1^{\mathrm{a}}$ & $0.11 \pm 0.1^{\mathrm{a}}$ & $2.8 \pm 0.1^{\mathrm{a}}$ & $2.84 \pm 0.1^{\mathrm{a}}$ & $2.85 \pm 0.07^{\mathrm{a}}$ \\
\hline CABA56 & $0.12 \pm 0.01^{\mathrm{a}}$ & $2.86 \pm 0.1^{\mathrm{a}}$ & $2.94 \pm 0.1^{\mathrm{a}}$ & $2.97 \pm 0.1^{\mathrm{a}}$ & $0.02 \pm 0.01^{\mathrm{a}}$ & $1.4 \pm 0.1^{\mathrm{a}}$ & $1.5 \pm 0.1^{\mathrm{a}}$ & $1.67 \pm 0.1^{\mathrm{a}}$ & $0.1 \pm 0.1^{\mathrm{a}}$ & $2.82 \pm 0.1^{\mathrm{a}}$ & $2.84 \pm 0.1^{\mathrm{a}}$ & $2.92 \pm 0.1^{\mathrm{a}}$ \\
\hline \multicolumn{13}{|l|}{$\begin{array}{c}L . \\
\text { plantarum }\end{array}$} \\
\hline CAKA28 & $0.1 \pm 0.1^{\mathrm{a}}$ & $2.84 \pm 0.1^{\mathrm{a}}$ & $2.9 \pm 0.07^{\mathrm{a}}$ & $2.9 \pm 0.1^{\mathrm{a}}$ & $0.03 \pm 0.1^{\mathrm{a}}$ & $1.64 \pm 0.1^{\mathrm{a}}$ & $1.7 \pm 0.1^{\mathrm{a}}$ & $1.74 \pm 0.1^{\mathrm{a}}$ & $0.08 \pm 0.1^{\mathrm{a}}$ & $2.79 \pm 0.1^{\mathrm{a}}$ & $2.85 \pm 0.1^{\mathrm{a}}$ & $2.85 \pm 0.1^{\mathrm{a}}$ \\
\hline CAKA34 & $0.11 \pm 0.1^{a}$ & $2.84 \pm 0.15^{\mathrm{a}}$ & $2.88 \pm 0.13^{\mathrm{a}}$ & $2.95 \pm 0.02^{\mathrm{a}}$ & $0.05 \pm 0.01^{\mathrm{a}}$ & $1.72 \pm 0.1^{\mathrm{a}}$ & $1.72 \pm 0.1^{\mathrm{a}}$ & $1.8 \pm 0.1^{\mathrm{a}}$ & $0.1 \pm 0.1^{\mathrm{a}}$ & $2.78 \pm 0.1^{\mathrm{a}}$ & $2.78 \pm 0.1^{\mathrm{a}}$ & $2.83 \pm 0.1^{\mathrm{a}}$ \\
\hline CAN23 & $0.1 \pm 0.1^{\mathrm{a}}$ & $2.8 \pm 0.02^{\mathrm{a}}$ & $2.8 \pm 0.1^{\mathrm{a}}$ & $2.87 \pm 0.1^{\mathrm{a}}$ & $0.01 \pm 0.01^{\mathrm{a}}$ & $1.27 \pm 0.1^{\mathrm{a}}$ & $1.28 \pm 0.1^{\mathrm{a}}$ & $1.57 \pm 0.1^{\mathrm{a}} 0$ & $0.017 \pm 0.1^{\mathrm{a}}$ & $2.78 \pm 0.1^{\mathrm{a}}$ & $2.78 \pm 0.1^{\mathrm{a}}$ & $2.8 \pm 0.1^{\mathrm{a}}$ \\
\hline CAN29 & $0.1 \pm 0.1^{\mathrm{a}}$ & $2.8 \pm 0.1^{\mathrm{a}}$ & $2.84 \pm 0.1^{\mathrm{a}}$ & $2.91 \pm 0.1^{\mathrm{a}} 0$ & $0.011 \pm 0.07^{\mathrm{a}}$ & $1.3 \pm 0.1^{\mathrm{a}}$ & $1.41 \pm 0.1^{\mathrm{a}}$ & $1.61 \pm 0.1^{\mathrm{a}}$ & $0.04 \pm 0.1^{\mathrm{a}}$ & $2.6 \pm 0.07^{\mathrm{a}}$ & $2.74 \pm 0.1^{\mathrm{a}}$ & $2.88 \pm 0.1^{\mathrm{a}}$ \\
\hline CAN36 & $0.13 \pm 0.1^{\mathrm{a}}$ & $2.9 \pm 0.1^{\mathrm{a}}$ & $2.95 \pm 0.1^{\mathrm{a}}$ & $2.97 \pm 0.1^{\mathrm{a}}$ & $0.1 \pm 0.02^{\mathrm{a}}$ & $1.65 \pm 0.13^{\mathrm{a}}$ & $1.7 \pm 0.1^{\mathrm{a}}$ & $1.77 \pm 0.1^{\mathrm{a}}$ & $0.09 \pm 0.1^{\mathrm{a}}$ & $2.84 \pm 0.1^{\mathrm{a}}$ & $2.85 \pm 0.1^{\mathrm{a}}$ & $2.87 \pm 0.02^{\mathrm{a}}$ \\
\hline CAN38 & $0.17 \pm 0.1^{\mathrm{a}}$ & $2.94 \pm 0.1^{\mathrm{a}}$ & $2.94 \pm 0.1^{\mathrm{a}}$ & $2.97 \pm 0.1^{\mathrm{a}}$ & $0.1 \pm 0.14^{\mathrm{a}}$ & $1.77 \pm 0.1^{\mathrm{a}}$ & $1.8 \pm 0.1^{\mathrm{a}}$ & $1.86 \pm 0.1^{\mathrm{a}}$ & $0.15 \pm 0.1^{\mathrm{a}}$ & $2.91 \pm 0.1^{\mathrm{a}}$ & $2.92 \pm 0.1^{\mathrm{a}}$ & $2.96 \pm 0.1^{\mathrm{a}}$ \\
\hline
\end{tabular}

Means are similar $(\mathrm{P}<0.05)$, they are indicated by the same letter "a".

The 20 strains were all able to ferment the both prebiotics FOS and lactulose. The small increase in the final OD600 values obtained after $30 \mathrm{~h}$ of incubation in the presence of this prebiotic was presumably due to the insufficient purity of the carbohydrates. The growth capability in the presence of FOS was particularly good for both Lactobacillus strains CAT19 and CABA16, with OD600 values of $2.84 \pm 0.1$ and $3 \pm 0.1$ respectively after $30 \mathrm{~h}$ of incubation. Also the lactulose allowed a good fermentation by the all strains, for obtaining an OD600 value even 3.0. FOS and lactulose were an effective growth substrates for all the 20 Lactobacillus strains, that reached OD600 values > 3.0. Compared to the FOS, lactulose had particularly more fermented by the Lactobacillus bacteria.

\subsection{Cholesterol Removal by Probiotic Lactobacillus Strains}

The reduction of cholesterol by 20 probiotic strains grown in medium supple- 
mented with $0.3 \%$ oxgall is shown in Figure 1 . All these were able to assimilate cholesterol at varying percentages. Analysis of variance showed that the percentage of cholesterol assimilation varied significantly $(\mathrm{P}<0.05)$ amongst probiotic strains even at the same incubation times (12 and $24 \mathrm{~h}$ ). The cholesterol assimilation ranged $15 \%-20 \%, 28 \%-40 \%$ and $34 \%-58 \%$ after 6 h, 12 $\mathrm{h}$, and $24 \mathrm{~h}$ of incubation, respectively. In particular, both probiotic Lactobacillus fermentum strains CAT19 and CABA16 showed significantly $(\mathrm{P}<0.05)$ higher cholesterol removal ability $(49 \% \pm 0.01 \%$ and $58 \% \pm 0.01 \%$, respectively) at $24 \mathrm{~h}$ of incubation as compared with the other strains. For all probiotic strains, the percentage of cholesterol removal increased significantly $(\mathrm{P}<0.05)$ as the incubation time increased.

\subsection{Deconjugation of bile Salts: Amount of Free Cholic Acid}

The deconjugation activities of 20 probiotic Lactobacillus strains towards sodium glycocholate, sodium taurocholate and their mixture are shown in Figure 2. All probiotics were able to deconjugate both salts and their mixture with varying amounts. The amount of liberated cholic acid varied significantly $(\mathrm{P}<0.05)$ and ranged from 0.12 to $0.40 \mathrm{mM}$ for sodium glycocholate, $0.1-0.33$ $\mathrm{mM}$ for sodium taurocholate and $0.15-0.41 \mathrm{mM}$ for their mixture. Particularly, the L. fermentum strains CAT19 and CABA16 showed significantly higher bile salt deconjugation activities compared with other strains $(\mathrm{P}<0.05)$. All probiotics deconjugated sodium glycocholate to a higher amounts than taurocholate and their mixture $(\mathrm{P}<0.05)$. Student's test indicated significant differences $(\mathrm{P}<$ 0.05 ) between probiotic bacteria in deconjugation of the same bile salt.

\subsection{Antioxidant Activity}

The antioxidant activity was evaluated by two different methods: $\mathrm{ABTS}^{+}$and DPPH and. The culture supernatant of 20 probiotic Lactobacillus strains exhibited high abilities to scavenge the radical $\mathrm{ABTS}^{+}(\mathrm{P}<0.05)$. These activities

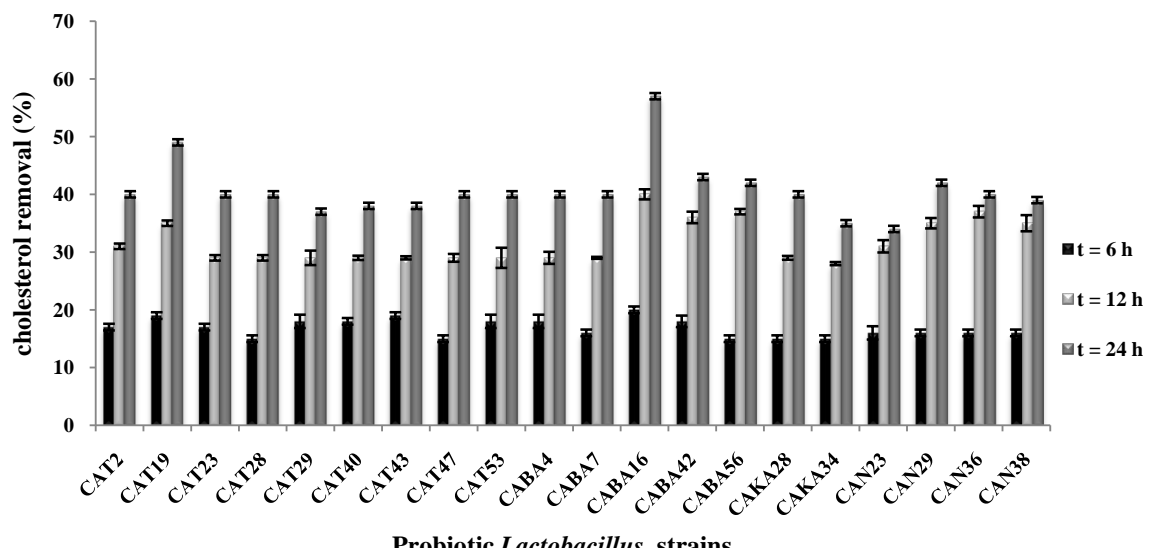

Figure 1. The cholesterol removal of 20 probiotic Lactobacillus strains inoculated in MRS supplemented with $100 \mu \mathrm{g} / \mathrm{mL}$ water-soluble cholesterol and $0.3 \%$ oxgall for 6,12 and 24 h at $37^{\circ} \mathrm{C}$. 
ranged from $19 \% \pm 1.4 \%$ to $52 \% \pm 1.57 \%$ (Figure 3 ). For DPPH method, the analysis showed significative variable percentage $(\mathrm{P}<0.05)$. We obtained a high antioxidant activities with $\mathrm{EC}_{50}$ ranged from important value $2.19 \pm 0.1 \mu \mathrm{g} / \mathrm{ml}$ to $5.19 \pm 0.11 \mu \mathrm{g} / \mathrm{ml}$ obtained for CABA16 and CAT43 respectively (Figure 4).

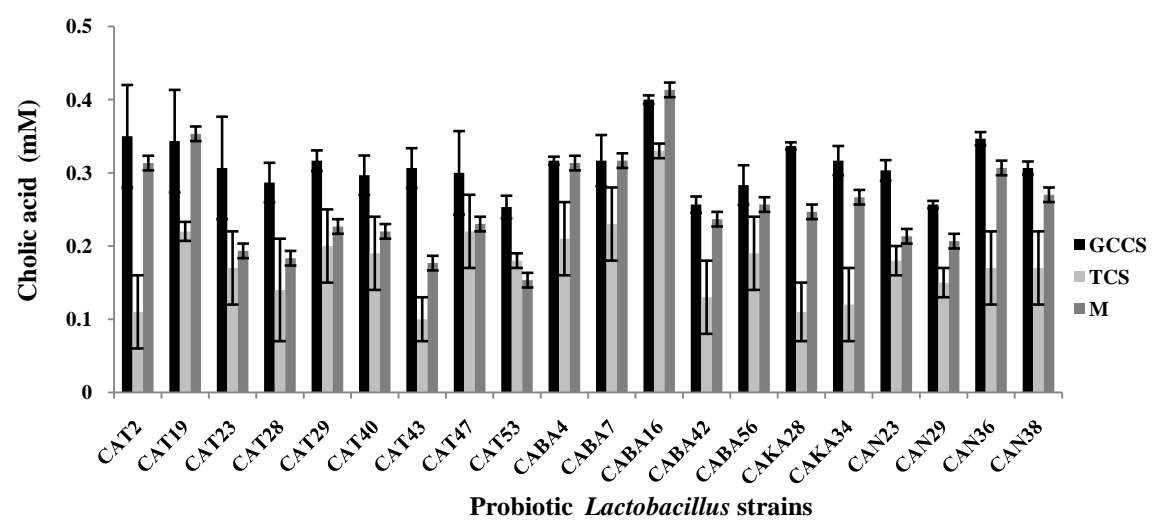

Figure 2. Bile salt deconjugation activities of the 20 probiotic Lactobacillus strains incubated in MRS supplemented with sodium glycocholate $(6 \mathrm{mM})$, sodium taurocholate (6 $\mathrm{mM}$ ) and their mixture $(4 \mathrm{mM})$ for $24 \mathrm{~h}$ at $37^{\circ} \mathrm{C}$. GCCS: sodium glycocholate; TCS: sodium taurocholate; M: Mixture.

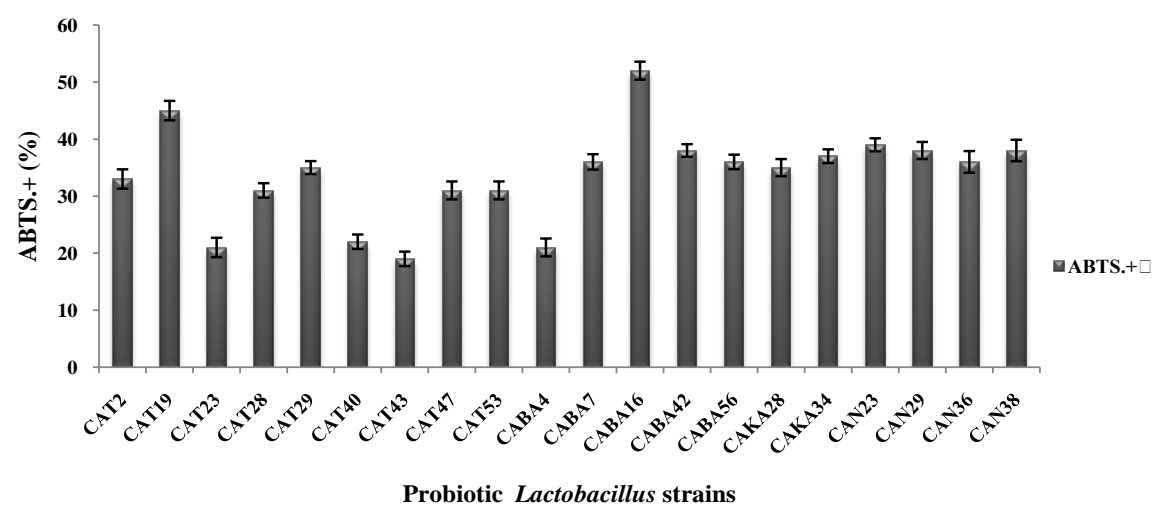

Figure 3. Antioxydant activities of 20 probiotic strains by $\mathrm{ABTS}^{+}$method.

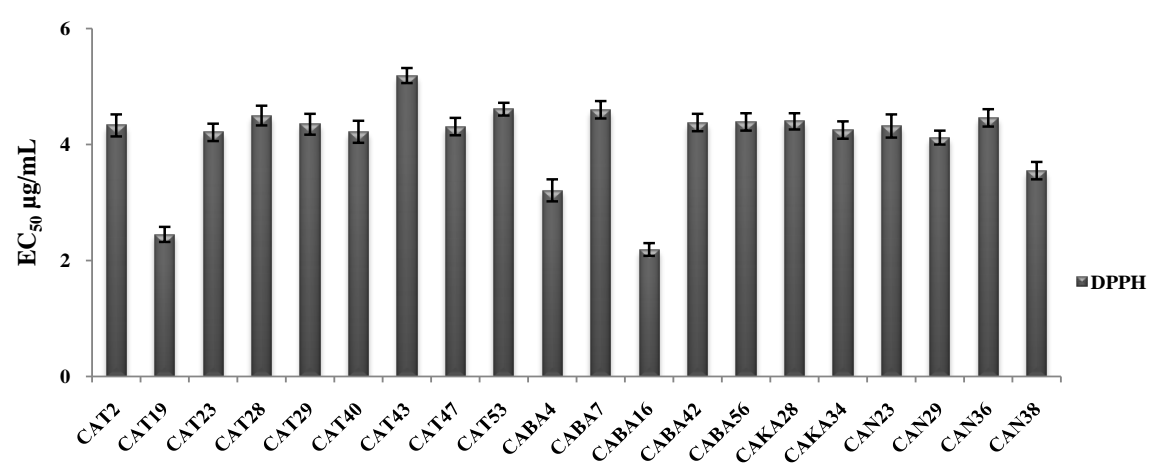

Probiotic Lactobacillus strains

Figure 4. Antioxydant activities of 20 probiotic Lactobacillus strains by DPPH method $\mathrm{EC}_{50}$ : Minimum antioxidant concentration required to reduce the initial DPPH reaction by $50 \%$. 


\section{Discussion}

Many researchs have interested in the positive effects of consumption of oligosaccharides on human health. Then, the aim of supplementation of prebiotic carbohydrates is the beneficial management of the gut microbiota [30]. It have demonstrated, in vivo, a significant increase of the colonic bifidobacteria due to the consumption of prebiotic [31]. Oligosaccharides are present in many products, such as fruits and milk and their adjunction in functional foods has been more increased [32]. So, by producing fermented foods with the suitable prebiotic, it is possible to improve the best growth of probiotic strains added as starter cultures.

In the present study, the fermentation of prebiotics by 20 Lactobacillus strains was analysed. In fact, all these strains were able to ferment both FOS and lactulose. Our results were similar to those obtained by Pennachia et al. [26] who cofirmed that $L$. plantarum and $L$. paracasei were able to assimilate FOS and lactulose with value of $\mathrm{OD}_{600} \geq 3$. Moreover, Saarela et al. [33] found that lactulose was the best fermented hydrocarbure by L. rhamnosus strains. In our study, the fermentation capability of prebiotics was not strain-dependent. In contrast, in another study on 28 lactic bacteria and bifidobacteria regarding their ability to ferment FOS was observed a species-dependent behaviour of fermentation [34]. The major studies of prebiotic effects indicated experiments done on the growth behaviour of total faecal microflora such as Lactobacillus, Bifidobacterium, Streptococcus,.. by batch culture.

Compared to FOS, lactulose was more assimilated by Lactobacillus strains. These results were similar to those revealed by Palframan et al. [35] who indicated a significant increase in the count of lactobacilli in fresh faecal slurry which was produced by adding lactulose to the batch culture fermenters; by contrast a significant decrease in their number when the FOS were added. The synbiotic system of prebiotic and probiotic is efficient if both components fit together [36]. Pennachia et al. [26] demonstrated that it would be useful to take considerably the specific utilization patterns of a probiotic before incorporating it into a product containing prebiotic substances, such as novel synbiotic fermented sausages. Also, they showed that it is possible to choose more than one prebiotic carbohydrate to stimulate the growth of a potential probiotic Lactobacillus strain to be included in novel starter culture in functional food.

High blood cholesterol was generally considered to be a risk for cardiovascular disease. The effects of probiotic bacteria on serum cholesterol levels have attracted much interest in recent years [37].

In our work, all tested probiotic strains were able to assimilate cholesterol. We revealed a high degree even of $57 \%$ which was obtained by $L$. fermentum strain CABA16 after $24 \mathrm{~h}$ of contact. These results were in accordance with other researchs which reported abilities of Lactobacillus and Bifidobacteria species even at $65 \%$ of cholesterol assimilation [10] [14]. Also, Lye et al. [17] demonstrated that potential probiotic bacteria $L$. acidophilus was able to diminish 
blood cholesterol. Moreover, Nguyen et al. [38] showed a 10\% of cholesterol assimilation by $L$. plantarum strains, isolated from infant faeces.

For all strains, the degree of cholesterol removal increased significantly $(\mathrm{P}<$ 0.05 ) as the incubation time increased. It is important to indicate that cholesterol activity would be bacterial growth and time dependent. In fact, probiotic strains growth may be influenced by cholesterol [14]. Besides, Lye et al. [17] reported, in their work, that the higer cholesterol assimilation was obtained in presence of oxgall than sodium salts.

There were three possible mechanisms may express the ability of probiotic strains to reduce cholesterol from the media. One was the co-precipitation of cholesterol with free bile salts [39]. A part of cholesterol was precipitated and resolubilised in the washing medium. This result was reported by Klaver and Van D er Meer [40], who indicated that cholesterol removal by lactobacilli was resulted to bile salts deconjugation by BSH activity of the probiotic strains. The second mechanism was the assimilation of cholesterol by the cells of probiotic bacteria. Cholesterol presented in fragmented-cells solution was attributed to the cholesterol assimilation by the cells of strains [41]. The third mechanism was the degradation of cholesterol by Lactobacillus strains. In this study, cholesterol could not be entirely recovered from the supernatant or washing fluid and fragmented-cells solution. Partial intake of cholesterol into the cells of the probiotic strain must produced, and some cholesterol may be degraded into a nutritional ingredients used for the growth of probiotic strains [14].

In this research, we enregistrated an important bile salt deconjugation for all tested probiotic strains. These results were in agreement with those obtained by Miremadi et al. [14] who reported that Lactobacillus and Bifidobacterium strains were able to deconjugate bile salts with a muximum of $56 \mathrm{mM}$ of free cholic acids.

As surfactants, conjugated bile salts participate to cholesterol micelle formation by enhancing cholesterol absorption in the small intestine [42]. Following bile salt deconjugation, the cholesterol micelle formation would be disrupted and thus the absorption of cholesterol would be difficult [43].

We also demonstrate that all 20 probiotic cultures deconjugated sodium glycocholate more efficiently than sodium taurocholate. These results are in agreement with those obtained by Ramasamy et al. [44] and Miremadi et al. [14]. Contrary to glycine, taurine metabolism provides the production of hydrogen sulphide, which is highly toxic to the host after deconjugation [45]. Thus, the property of deconjugating glycine better than taurine is a fundamental characteristic for probiotics [46]. In our study, all strains showed higher deconjugating activity on sodium glycocholate than sodium taurocholate. It could be obvious that probiotics exercise deconjugation activities as a defensive mechanism against the toxic effects of conjugated bile salts [47]. The fact that sodium glycocholate is the predominant component of bile salts in the human intestine, it has been proposed that strains which may deconjugate sodium glycocholate may be more effective in lowering serum cholesterol [48]. With high activity, it is likely that 
these strains can exert a deconjugation also in vivo. Furthermore, the bacterial genera which would be most likely to be used as probiotics (Bifidobacterium and Lactobacillus) are not capable of dehydroxylating conjugated bile salts, and therefore the majority of the degradation products of BSH. A probiotic strain can be precipitated and excreted in the stool [42].

Lactic acid bacteria have antioxidant mechanisms such as reduction of glutathione, NADH oxidase, NADH peroxidase, thiol compounds, metal ion chelating ability, trapping reactive oxygen species and reducing activity. These protective capacities result in antioxidant properties for certain lactobacilli bacteria and possibly provide additional dietary sources of antioxidants or probiotic bacteria capable of reducing oxidative stress [15].

In this study, the antioxidant effects of 20 probiotics were observed by two different methods, including scavenging of $\mathrm{ABTS}^{+}$and DPPH radicals. We showed an important activities for all strains. These results were similar to those noted by Meira et al. [49] and Pieniz et al. [24] who reported that L. plantarum, L. casei and Enterococcus durans, isolated from sheep, were also endowed with important antioxidant activities. It should be noted that our strains have strong potential antioxidants and can be used to reduce oxidative phenomena in food products. Nevertheless, using intact cells as delivery vehicles passing through the gastrointestinal tract, intracellular constituents released by lactic acid bacteria into the gastrointestinal tract may also be antioxidants [24].The consumption of food containing lactic acid bacteria can be recommended as healthy. It is well established that a wide variety of oxygenated free radicals are produced continuously in food and in the human body [50]. In addition to the long history of consumption, which proves the beneficial effects of probiotic lactic acid bacteria, it has been noted that these microorganisms are desirable for use in the production of various functional foods and therefore for human health.

\section{Conclusion}

The results of prebiotic experiments could open up to a relevant in vivo test that would inform if prebiotics could support the survival of a probiotic strain in the human intestine like adhesion properties. Furthermore, the current study suggests that all probiotic strains studied were able to remove cholesterol and deconjugate both sodium glycocholate and sodium taurocholate and their mixture with high degree. For another beneficial effect, these Lactobacillus strains exhibited antioxidant activities, which were evidenced with both methods. Therefore, investigations may be warranted to explain its potential health benefit and its application as promising probiotic strain in the feed industry especially where cholesterol reduction is the main objective.

\section{Acknowledgments}

A special thank to Pr. Mnasser Hassouna: École Supérieure des Industries Alimentaires de Tunis (ESIAT), Tunis, Tunisia for the realization of this work. 


\section{References}

[1] Haghshenas, B., Nami, Y., Abdullah, N., Radiah, D., Rosli, R. and Khosroushahi, A.Y. (2015) Anticancer Impacts of Potentially Probiotics Acetic Acid Bacteria Isolated from Traditional Dairy Microbiota. LWT Food Science and Technology, 60, 690-697.

[2] Guarner, F., Khan, A. G., Garisch, J., Eliakim, R., Gangl, A., Thomson, A., Krabshuis, J. and Lemair, T. (2008) Probiotics and Prebiotics. World Gastroenterology Organisation Practice Guideline.

[3] Casiraghi, M.C., Canzi, E., Zanchi, R., Donati, E. and Villa, L. (2007) Effects of a Synbiotic Milk Product on Human Intestinal Ecosystem. Journal of Applied Microbiology, 103, 499-506. https://doi.org/10.1111/j.1365-2672.2006.03273.x

[4] Huebner, J., Wehling, R.L. and Hutkins, R.W. (2007) Functional Activity of Commercial Prebiotics. International Dairy Journal, 17, 770-775.

[5] Shah, N.P. (2001) Functional Foods, Probiotics and Prebiotics. Food Technology, 55, 46-53.

[6] Isolauri, E. (2004) The Role of Probiotics in Paediatrics. Current Paediatrics, 14, 104-109.

[7] Roberfroid, M.B. (2000) Prebiotics and Probiotics: Are They Functional Foods. American Journal of Clinical Nutrition, 71, 1682-1687.

[8] Park, S.F. and Kroll, R.G. (1993) Expression of Lysteriolysin and Phosphatidylinositol-Specific Phospholipase C Is Repressed by the Plant-Derived Molecule Cellobiose in Listeria monocytogenes. Molecular Microbiology, 8, 653-661. https://doi.org/10.1111/j.1365-2958.1993.tb01609.x

[9] Fric, P. (2007) Probiotics and Prebiotics-Renaissance of a Therapeutic Principle. European Journal of Medicinal Chemistry, 2, 237-270. https://doi.org/10.2478/s11536-007-0031-5

[10] Wang, J., Zhang, H., Chen, X., Chen, Y., Menghebilige and Bao, Q. (2012) Selection of Potential Probiotic Lactobacilli for Cholesterol-Lowering Properties and Their Effect on Cholesterol Metabolism in Rats Fed a High-Lipid Diet. Journal of Dairy Science, 95, 1645-1654. https://doi.org/10.3168/jds.2011-4768

[11] Shahidi, F. (2012) Nutraceuticals, Functional Foods and Dietary Supplements in Health and Disease. Journal of Food and Drug Analysis, 22, 226-230.

[12] Mann, G.V. and Spoerry, A. (1974) Studies of a Surfactant and Cholesteremia in the Maasai. American Journal of Clinical Nutrition, 27, 464-469.

[13] Park, S.C., Hwang, M.H., Kim, Y.H., Kim, J.C., Song, J.C., Lee, K.W., Jeong, K.S., Rhee, M.H., Kim, K.S. and Kim, T.W. (2006) Comparison of pH and Bile Resistance of Lactobacillus acidophilus Strains Isolated from Rat, Pig, Chicken, and Human Sources. World Journal of Microbiology and Biotechnology, 22, 35-37. https://doi.org/10.1007/s11274-005-4856-2

[14] Miremadi, F., Ayyash, M., Sherkat, F. and Stojanovska, L. (2014) Cholesterol Reduction Mechanisms and Fatty Acid Composition of Cellular Membranes of Probiotic Lactobacilli and Bifidobacteria. Journal of Functional Foods, 9, 295-305.

[15] Wang, Y.P., Xu, N., Xi, A.D., Ahmed, Z., Zhang, B. and Bai, X.J. (2009) Effects of Lactobacillus plantarum MA2 Isolated from Tibet Kefir on Lipid Metabolism and Intestinal Microflora of Rats Fed on High-Cholesterol Diet. Applied in Microbiology and Biotechnology, 84, 341-347. https://doi.org/10.1007/s00253-009-2012-X

[16] Ataie-Jafari, A., Larijani, B., Majd, H.A. and Tahbaz, F. (2009) CholesterolLowering Effect of Probiotic Yogurt in Comparison with Ordinary Yogurt in Mildly 
to Moderately Hypercholesterolemic Subjects. Annals of Nutrition and Metabolism, 54, 22-27. https://doi.org/10.1159/000203284

[17] Lye, H.S., Rusul, G. and Liong, M.T. (2010) Removal of Cholesterol by Lactobacilli via Incorporation and Conversion to Coprostanol. Journal of Dairy Science, 93, 1383-1392. https://doi.org/10.3168/jds.2009-2574

[18] Zhang, F., Hang, X., Fan, X., Li, G. and Yang, H. (2007) Selection and Optimization Procedure of Synbiotic for Cholesterol Removal. Anaerobe, 13, 185-192.

[19] Ha, C.G., Cho, J.K., Lee, C.H., Chai, Y.G., Ha, Y.A. and Shin, S.H. (2006) Cholesterol Lowering Effect of Lactobacillus plantarum Isolated from Human Feces. Journal of Microbiology and Biotechnology, 16, 1201-1209.

[20] Corzo, G. and Gilliland, S.E. (1999) Bile Salt Hydrolase Activity of Three Strains of Lactobacillus acidophilus. Journal of Dairy Science, 82, 472-480. https://doi.org/10.3168/jds.S0022-0302(99)75256-2

[21] Liong, M.T. and Shah, N.P. (2005) Acid and Bile Tolerance and Cholesterol Removal Ability of Lactobacilli Strains. Journal of Dairy Science, 88, 55-66. https://doi.org/10.3168/jds.S0022-0302(05)72662-X

[22] Walker, D.K. and Gilliland, S.E. (1993) Relationship among Bile Tolerance, Bile Salt Deconjugation, and Assimilation of Cholesterol by Lactobacillus acidophilus. Journal of Dairy Science, 76, 956-961. https://doi.org/10.3168/jds.S0022-0302(93)77422-6

[23] Dambekodi, P.C. and Gilliland, S.E. (1998) Incorporation of Cholesterol into the Cellular Membrane of Bifidobacterium longum. Journal of Dairy Science, 81, 18181824. https://doi.org/10.3168/jds.S0022-0302(98)75751-0

[24] Pieniz, S., Andreazza, R., Anghinoni, T., Camargo, F. and Brandelli, A. (2014) Probiotic Potential, Antimicrobial and Antioxidant Activities of Enterococcus durans Strain LAB18s. Food Control, 37, 251-256.

[25] Mahmoudi, I., Ben Moussa, O., Khaldi, T.E., Kebouchi, M., Soligot, C., Le Roux, Y. and Hassouna, M. (2016) Functional in Vitro Screening of Lactobacillus Strains Isolated from Tunisian Camel Raw Milk toward Their Selection as Probiotic. Small Ruminant Research, 137, 91-98.

[26] Pennacchia, C., Vaughan, E.E. and Villani, F. (2006) Potential Probiotic Lactobacillus Strains from Fermented Sausages: Further Investigations on Their Probiotic Properties. Meat Science, 73, 90-101.

[27] Pilch, P., Radziszewski, P. and Maciukiewicz, P. (2012) Prostate Cancer Dependance upon Cholesterol, Statins and Diet. Rak Gruczołu Krokowego a Cholesterol, Statyny i Dieta, 65, 31-37.

[28] Rossini, K., Noreña, C.P.Z., Olivera, F.C. and Brandelli, A. (2009) Casein Peptides with Inhibitory Activity on Lipid Oxidation in Beef Homogenates and Mechanically Deboned Poultry Meat. LWT Food Science and Technology, 42, 862-867.

[29] Brand-Williams, W., Cuvelier, M.E. and Berset, C. (1995) Use of Free Radical Method to Evaluate Antioxidant Activity. LWT Food Science and Technology, 2, 25-30.

[30] Kolida, S., Tuohy, K. and Gibson, G.R. (2002) Prebiotic Effects of Inulin and Oligosaccharydes. British Journal of Nutrition, 87, S193-S197. https://doi.org/10.1079/BJN/2002537

[31] Gibson, G.R., Beatty, E.R., Wang, X. and Cummings, J.H. (1995) Selective Stimulation of Bifidobacteria in the Human Colon by Oligofructose and Inulin. Gastroenterology, 108, 975-982.

[32] Delzenne, N.M. (2003) Oligosaccharides: State of the Art. Proceedings of the 
Nutrition Society, 62, 177-182. https://doi.org/10.1079/PNS2002225

[33] Saarela, M., Hallamaa, K., Mattila-Sandholm, T., and Matto, J. (2003) The Effect of Lactose Derivates Lactulose, Lactitol and Lactobionic Acid on the Functional and Technological Properties of Potentially Probiotic Lactobacillus Strains. International Dairy Journal, 13, 291-302.

[34] Kaplan, H. and Hutkins, R.W. (2000) Fermentation of Fructooligosaccharides by Lactic Acid Bacteria and Bifidobacteria. Applied Environmental Microbiology, 66, 2682-2684. https://doi.org/10.1128/AEM.66.6.2682-2684.2000

[35] Palframan, R.J., Gibson, G.R. and Rastall, R.A. (2002) Effect of $\mathrm{pH}$ and Dose on the Growth of Gut Bacteria on Prebiotic Carbohydrates in Vitro. Anaerobe, 8, 287-292. https://doi.org/10.1006/anae.2002.0434

[36] Kneifel, W., Rajal, A. and Kulbe, K.D. (2000) In Vitro Growth Behaviour of Probiotic Bacteria in Culture Media with Carbohydrates of Prebiotic Importance. Microbiol Ecology in Health and Disease, 12, 27-34. https://doi.org/10.1080/089106000435563

[37] Mathara, J.M., Schillinger, U., Guigas, C., Franz, C., Kutima, P.M., Mbugua, S.K., Shin, H.K. and Holzapfel, W.H. (2008) Functional Characteristics of Lactobacillus spp. from Traditional Maasai Fermented Milk Products in Kenya. International Journal of Food Microbiology, 126, 57-64.

[38] Nguyen, T.D.T., Kang, J.H. and Lee, M.S. (2007) Characterization of Lactobacillus plantarum PH04, a Potential Probiotic Bacterium with Cholesterol-Lowering Effects. International Journal of Food Microbiology, 113, 358-361.

[39] Guo, L.-D., Yang, L.-J. and Huo, G.-C. (2011) Cholesterol Removal by Lactobacillus plantarum Isolated from Homemade Fermented Cream in Inner Mongolia of China Czech. Journal of Food Science, 3, 219-225.

[40] Klaver, F.A.M. and Van Der Meer, R. (1993) The Assumed Assimilation of Cholesterol by Lactobacilli and Bifidobacterium bifidum Is Due to Their Bile Salt-Deconjugating Activity. Applied Environmental Microbiology, 59, 1120-1124.

[41] Grill, J.P., Cayuela, C., Antoine, J.M. and Schneider, F. (2000) Effects of Lactobacillus amylovorus and Bifidobacterium breve on Cholesterol. Letters in Applied Microbiology, 31, 154-156. https://doi.org/10.1046/j.1365-2672.2000.00792.x

[42] Begley, M., Hill, C., Cormac, G. and Gahan, M. (2006) Bile Salt Hydrolase Activity in Probiotics. Applied and Environmental Microbiology, 72, 1729-1738. https://doi.org/10.1128/AEM.72.3.1729-1738.2006

[43] Cheeke, P.R. (2000) Actual and Potential Applications of Yucca schidigera and Quillaja saponaria Saponins in Human and Animal Nutrition. Journal of Animal Science, 77, 1-10. https://doi.org/10.2527/jas2000.00218812007700ES0009x

[44] Ramasamy, K., Abdullah, N., Wong, M.C.V.L., Karuthan, C. and Ho, Y.W. (2010) Bile Salt Deconjugation and Cholesterol Removal from Media by Lactobacillus Strains Used as Probiotics in Chickens. Journal of the Science of Food and Agriculture, 90, 65-69. https://doi.org/10.1002/jsfa.3780

[45] Ridlon, J.M., Kang, D.J. and Hylemon, P.B. (2010) Isolation and Characterization of a Bile Acid Inducible $7 \alpha$-Dehydroxylating Operon in Clostridium hylemonae TN271. Anaerobe, 16, 137-146.

[46] Begley, M., Cormac, G.M., Gahan and Hill, C. (2005) The Interaction between Bacteria and Bile. FEMS Microbiology Reviews, 29, 625-651.

[47] Moser, S.A. and Savage, D.C. (2001) Bile Salt Hydrolase Activity and Resistance to Toxicity of Conjugated Bile Salts Are Unrelated Properties in Lactobacilli. Applied 
Environmental Microbiology, 67, 3476-3480.

https://doi.org/10.1128/AEM.67.8.3476-3480.2001

[48] Brashears, M.M., Gilliland, S.E. and Buck, L.M. (1998) Bile Salt Deconjugation and Cholesterol Removal from Media by Lactobacillus casei. Journal of Dairy Science, 81, 2103-2110. https://doi.org/10.3168/jds.S0022-0302(98)75785-6

[49] Meira, S.M.M., Helfer, V.E., Velho, R.V., Lopes, F.C. and Brandelli, A. (2012) Probiotic Potential of Lactobacillus spp. Isolated from Brazilian Regional Ovine Cheese. Journal of Dairy Research, 79, 119-127. https://doi.org/10.1017/S0022029911000884

[50] Lobo, V., Patil, A., Phatak, A. and Chandra, N. (2010) Free Radicals, Antioxidants and Functional Foods: Impact on Human Health. Pharmacognosy Reviews, 4, 118126. https://doi.org/10.4103/0973-7847.70902

Submit or recommend next manuscript to SCIRP and we will provide best service for you:

Accepting pre-submission inquiries through Email, Facebook, LinkedIn, Twitter, etc. A wide selection of journals (inclusive of 9 subjects, more than 200 journals) Providing 24-hour high-quality service User-friendly online submission system Fair and swift peer-review system Efficient typesetting and proofreading procedure Display of the result of downloads and visits, as well as the number of cited articles Maximum dissemination of your research work

Submit your manuscript at: http://papersubmission.scirp.org/

Or contact aim@scirp.org 